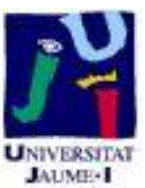

Título artículo / Títol article: Positive musical experiences in education: music as a social praxis

Autores / Autors

Cabedo Mas, Alberto ; Díaz Gómez, Maravillas

Revista:

Music Education Research, 2013, Volume 15, Issue 4

Versión / Versió:

Post-print del autor

Cita bibliográfica / Cita bibliogràfica (ISO 690):

url Repositori UJI:
CABEDO-MAS, Alberto; DÍAZ-GÓMEZ, Maravillas. Positive musical experiences in education: music as a social praxis. Music Education Research, 2013, vol. 15, no 4, p. $455-470$.

http://hdl.handle.net/10234/94133 


\title{
Positive musical experiences in education: music as a social praxis
}

\author{
Alberto Cabedo-Mas ${ }^{\mathrm{a} *}$ and Maravillas Díaz-Gómez ${ }^{\mathrm{b}}$ \\ ${ }^{a}$ Department of Education, Facultat de Ciències Humanes $i$ Socials, University Jaume I of \\ Castellón, Av. Vicent Sos Baynat s/n, Castellón de la Plana 12071, Spain; ${ }^{b}$ Department of \\ Didactics of Musical, Plastic and Corporal Expression, University of the Basque Country \\ AQ12 Barrio de Sarriena s/n Leioa 48940, Spain
}

(Received 4 September 2012; final version received 20 December 2012)

\begin{abstract}
This research explores the possibilities of music education in relation to improved interpersonal and social relationships. The paper focuses mainly on music teachers in primary and secondary schools in Spain. It aims to collect, analyse and provide arguments to defend a musical education that integrates musical diversity and facilitates the acquisition of positive musical experiences. Interviews were carried out with relevant national and international figures in musical education, educational theory or critical thinking. A qualitative approach was taken to evaluate the responses from this purposeful sample. The results highlight the need to foster participatory musical activity. The acquisition of positive musical experiences encourages students to extend their musical lives beyond the classroom by recognising different musical identities and promoting improved coexistence.
\end{abstract}

Keywords: music; education; musical experience; coexistence; musical practice; primary and secondary education

\section{Introduction}

This paper presents an interrogative study dealing with music education and its implications in the development of attitudes aimed at enhancing coexistence between people and cultures. Bearing in mind that the efforts of music education need to focus on improving students' musical and artistic training, the educational approach advocated in this paper is one that opens up space to develop competences in learning how to live together. To this end, we explore principles and guidelines for music education that have the potential to build connections between people, enabling them to strengthen and enhance interpersonal and social relationships. It has been argued that the acquisition of musical experiences can help to develop students' musical skills and at the same time foster the construction of intersubjective connections between students, thereby enriching coexistence.

This research aims to show and provide arguments for the importance of seeking out proposals and guidelines that encourage students to live positive musical experiences while they develop music learning. For this purpose, we collected, compiled and analysed original data resulting from responses from leading figures in the field of education and music education. These responses directly addressed the

\footnotetext{
*Corresponding author. Email: cabedoa@uji.es 
thematic focus of the research. Through questions, we proposed living forms of answers and knowledge (Latorre 2003). The study was principally addressed to music teachers and professionals in the field of music education.

We are aware that each geographical and social context has certain peculiarities that have an effect on the specificity of each educational reality. In this study, therefore, we focus on music education in primary and secondary schools in Spain. The Spanish socio-educational context conforms to the international guidelines on the learning and teaching of music. However, the specific educational reality requires Spanish music education to attend to the specific features that correspond to its own particularities.

\section{Musical experience and education: preliminary considerations and some current proposals}

One of the theories that may fully describe the nature of musical experience in education comes from the music literature referring to musical meaning, ideology and education addressed by Green (1988). For this author, a specific musical experience results from the complex relationship between the musical subject and object. This experience, therefore, arises in relation to what music means to each person. Indeed, it depends mainly on the meanings an individual receives from music - whether in the processes of music production, distribution and reception - and may, therefore, vary according to the responses to these meanings.

Green acknowledges two different musical meanings that coexist in every musical experience: the inherent or inter-sonic (2008), and the delineated meanings. Both arise from our response to music; however, the former occurs when both the sign and the object consist of musical materials; that is, the sound, a musical material we hear, is identified as other musical materials 'decoded' as notes, chords and phrases. The familiarity with a certain musical style may result in the reception of a greater inherent significance. In contrast, delineated meanings arise from the extramusical associations that the musical materials transmit to us; that is, the sound we hear evokes memories related to the various contexts of our lives. These meanings do not only refer to concrete extramusical objects, places or situations, but they also include the social contexts that characterise each particular music style. Thus, individual musical experience is understood only in the light of collective social meanings and structures. Therefore, individual experience is neither isolated nor really immediate but mediated through social history (Green 1988, 42).

Taking the above into account, music education should endeavour to seek positive musical experiences in the music classroom. Achieving musical practices that result in affirmative musical meanings and experiences will enhance students' musical training. A musical education which creates a space to develop interpersonal competences undoubtedly requires these experiences. Through shared musical practices, music may become a channel for connection that promotes the integration of and the dialogue between interpersonal and intercultural diversity. We consider that identity - including musical identity - arises from a personal construction that is socially mediated, and it necessarily emerges through dialogue and interaction with others. This dialogue should be always based on recognition policies. This Hegelian idea of recognition is understood here through the principles of Honneth (1997), and from which social and cultural conflicts - including those concerning the musical 
dimension - should not be considered only as a result of a mere struggle caused by material interests in opposition, but also as a struggle for recognition which necessarily arises in response to experiences of disrespect or denial of identity (Honneth 1996, 9-10). The challenge of human coexistence, based on relationships of mutual respect among individuals and societies, lies in the fact that we know and positively value coexistence not only between equals but also, and above all, between those who are different.

In this vein, music education is considered to have evolved competently in recent decades, incorporating new forms and styles, and adapting to a dynamic and changing society. This curricular and methodological expansion in music teaching and learning has opened the way to approaches that consider music education as an appropriate vehicle for developing students' intercultural skills.

Previously, music education mainly focused on training students in those musical styles to which greater educational value had been attributed. In the latter half of the twentieth century, music learning was limited almost exclusively to knowledge that was part of the dominant musical tradition in industrial societies, namely classical music (Martin 1995, 10).

The open methodologies of music learning developed in the second half of the last century - Orff, Dalcroze, Willems, Kodaly and so on - marked a breakthrough in access to music education for many people. Music should not be considered as an elitist art, but something to be practiced and enjoyed by everyone. This revolution in music education also opened doors to research into new ways of transmitting musical knowledge. Several music educators focused on the development of creativity Shafer, Paynter or Self - and contributed to the debate on what the main objectives of learning music in schools should be. Furthermore, during the 1970s attempts were made to introduce new musics and musical knowledge into formal curriculums. Endeavours to introduce Western popular musics into music education (Shepherd et al. 1977; Swanwick 1968; Vulliamy and Lee 1976), in parallel with the incorporation of folk musics, including non-Western traditions - known as world musics (Small 1977; Volk 1998), were accompanied by a critical theoretical conceptualisation and rethinking of the music teaching mechanisms in formal settings.

These new approaches in music education involving some of the aforementioned principles in music learning and teaching were necessarily questioned. One of the issues that first emerged was the deconstruction of the idea of musical autonomy from the social contexts, as a distinction of the imaginary of good art and good music. The highest educational value of music arose when it could be said to possess certain properties - such as universality, eternality, complexity and originality (Green 2003, 7) - that were directly linked to the concept of autonomy. These properties were connected to specific musical styles, and were lacking or less prolific in other styles. Providing music with autonomy from social contexts entailed an increase in its educational value. The inclusion of this new body of musical literature in formal settings necessarily led to a rethinking of these issues (Clarke 2003; Leppert and McClary 1987; McClary 1987; Wolff 1987).

Spain did not open up to new concepts in music education in earnest until the 1990s, with the educational reform of the LOGSE (Organic Law of General Organization of the Education System 1990). However, the new musics introduced came mainly from traditional folk music of the Autonomous Communities (Ibarretxe Txakartegi and Díaz Gómez 2008, 343). Arguments were soon put forward for the 
educational value of certain vernacular music styles (Torrego Egido 2005). This educational reform rapidly adapted Spanish music education to the current global trends in music education. However, these realities are still lacking in the musics and music texts used in the classroom. Music teachers often lack the training to deal with modern popular music, which leads music consumption among primary and secondary school students; they may also feel uncomfortable with emerging musical areas, such as new technologies in music education. The same situation may occur when incorporating the musical and cultural realities of immigrant students into the music classroom (Díaz Gómez and Ibarretxe Txakategui 2008; Ibarretxe Txakartegi 2005, 2006).

General education and, specifically, music education, encounter serious difficulties in incorporating the dynamic cultural diversity of our societies (Joseph and Southcott 2009). Today, the plurality in the understanding of the musical experience is so marked that philosophers and music education theorists, let alone musicians and music teachers, cannot come to grip with all the factors that intervene in this diversity within the music classroom (Green 2005, 77). Perhaps one way to promote the integration of different musical identities - or students' musical cultures (McCarthy 2010) - in music education would be to develop students' musicality, rather than merely including diversity in formal settings. A prescriptive and homogeneous approach towards intercultural music education may actually reinforce differences, by ignoring inflections in the musical identity that transcend the purely cultural. Reimer (1993) states that all music is, at some point, like all other music; it is like some other music and is not like any music. O'Flynn $(2005,193)$ adds that what counts as the same, similar and different depends heavily on a wide range of social and individual contexts.

Dillon $(2007,218)$ suggests developing musical education through an analysis of the way music practice is present by reflecting on three fundamental questions: where is music in the teacher's life? where is music in the student's life? and where is music in the life of a school? This analysis necessarily leads to a rethinking of the music teacher's role. In a musical approach focusing on the integration of musical diversity, the teacher must renounce the role of sole constructor of musical knowledge and endeavour to create optimal spaces and environments for the students' educational development; the teacher should, therefore, become a cultural manager (Dillon 2005). This approach is consistent with the need to propose a comprehensive music education in accordance with today's social context: the need to teach music globally (Campbell 2004).

Ensuring global access to music education, integrating this diversity, is one of the biggest challenges facing contemporary music educators. To this end, several initiatives focus on promoting the development of cultural life in societies, recognising that, as Gordon $(2007,394)$ notes, the artistic culture of a society is not necessarily determined by the number of virtuosos but by the percentage of the population who actively participate and is engaged in music making.

This active approach in music education coincides with proposals that defend praxial music education (Elliott 1995; Regelski 2004, 2009), and that highlights the need to encourage and empower people so that musical activities can improve the lives of others, the community, society and the culture in general. From this approach, praxial music education 'holds that school and community music teachers should be prepared to teach thoughtfully, artistically, educatively, caringly, and 
democratically for the betterment of students as music makers, listeners, and socially just citizens' (Elliott 2012, 452).

Criticism of the idea of music's autonomy from its social contexts as a distinctive feature of greater educational value has recently been challenged. Current trends defend the value of retrieving the notion of autonomy in some logical moments during the music practice. Such moments may enhance the acquisition of positive musical experiences, allowing music to cross boundaries (Green 2005). An affirmative positive response to inherent musical meanings can lead to an improvement towards the delineations a musical style can give rise to, thus enhancing the holistic musical experience. In this regard, recent research has set out to incorporate elements of informal music learning from Western popular music - which leads student's musical consumption and is the genre they feel most familiar with - in formal music education settings (Campbell 1998; Feichas 2010; Folkestad 2005, 2006; Green 2002, 2008; Karlsen 2010; Oliveira 2004; Väkevä 2010; Wright and Kanellopoulos 2010).

Green (2008) advocates integrating informal musical learning approaches into formal settings by adapting certain features. Table 1 sets forth the educational principles that characterise this learning.

Adopting and adapting some of these characteristics in Spanish primary and secondary music education settings could encourage integration of students' musical diversity by bringing together individual and collective musical identities and fostering new relationships of positive coexistence.

\section{Methods}

The main purpose of the research is to identify mechanisms and to provide arguments that enable the music teacher to build these optimal spaces in formal settings for music learning, thereby enabling students to experience positive responses to musical meanings. To this end, information was gathered through an interview, on the grounds that we consider interviews to be an effective research instrument. The following question was addressed to the participants:

What are the educative principles that promote significant musical practices and enhancing musical experiences?

Table 1. Elements from informal music learning in formal settings.

Educative principles from informal learning adapted to the music classroom (Green 2008)

1 The music is chosen by students.

2 Musical notation is absent or rare, and skill-acquisition involves copying recordings by ear.

3 Learning takes place alone, as well as collectively, alongside friends, through conscious and unconscious acquisition and exchange of skills and knowledge, including little or no adult supervision and guidance.

4 From the beginning the musical work is global and approached holistically, so there is no progressive learning plan based on difficulties.

5 It provides a special interest in listening, musical composition and improvisation, thus encouraging creativity. 
We collected data from semi-structured interviews which provided ideas, opinions and experiences about musical education in the pursuit of positive musical experiences. At the same time, we were able to compare and analyse the information obtained from a review of each respondent's published work. This study based principally on the answers, opinions and experiences of these participants, is AQ1 therefore, framed within the qualitative paradigm. As Kvale $(2011,29)$ points out, qualitative methods have become key methods in social research since the 1980s. The research is, therefore, framed within a model of social research that addresses issues and questions of people's behaviour within their social context. It provides not only answers to problems identified in real educational situations, but also clarifies the concepts that have direct or indirect connection with such issues (Cohen and Manion 1990, 74; Swanwick 1984, 197).

The initial sample consisted of 25 participants, chosen according to a series of predetermined criteria detailed below. The choice of the participants for the sample was carefully debated and agreed on. First, we hoped to include music educators, music education sociologists, critical musical thinkers and philosophers working in the area of peace studies. The participants were all leading figures in the Spanish and international arena whose bibliography and written works we had previously studied. They undertook or had undertaken their professional activities in renowned universities and research centres. Second, in order to obtain answers that approached the question from different perspectives, it was crucial to extend the sample to different contexts of learning. To this end, we selected authors who were working in a range of countries and educational realities. Likewise, third, we also chose authors whose published works address complementary perspectives on issues related to music education, personal and social identity, cultural and musical diversity or the concept of coexistence. The plurality of perspectives and approaches is considered to be a significant factor in this field of research; our sample, therefore, had to be consistent with this philosophy.

The research question put to the respondents had been previously validated by five experts in the fields of musical education and educational theory. Respondents were considered as authorities throughout the research. In general, they provided written responses to the question. Experts were given the opportunity to reflect, modify and analyse their responses as many times as they required. In one particular case, a respondent preferred to respond to the question by telephone, and the response was duly recorded. In order to ensure strict parity with the other data collected, this interview was not directed or mediated in any way. The question had previously been sent out and the respondent was asked for her views on this issue only. The interviewer's role was exclusively to maintain the channel of communication. The entire transcription was later returned to the respondent, who was able to modify any parts she deemed appropriate.

In total, 19 responses were obtained, representing a participation rate of $76 \%$ of the initial sample. In accordance with prior expectations, the information came from a range of locations and referred to educational realities in 12 different countries: Argentina, Australia, Austria, Brazil, Finland, Germany, Ireland, Portugal, the UK, the USA, Spain and Switzerland.

A qualitative approach was taken to evaluate the data (Flinders and Richardson 2002, 1167-72). A large number of varying thematic issues, references and perspectives related to the question emerged from an initial reading of the responses. 


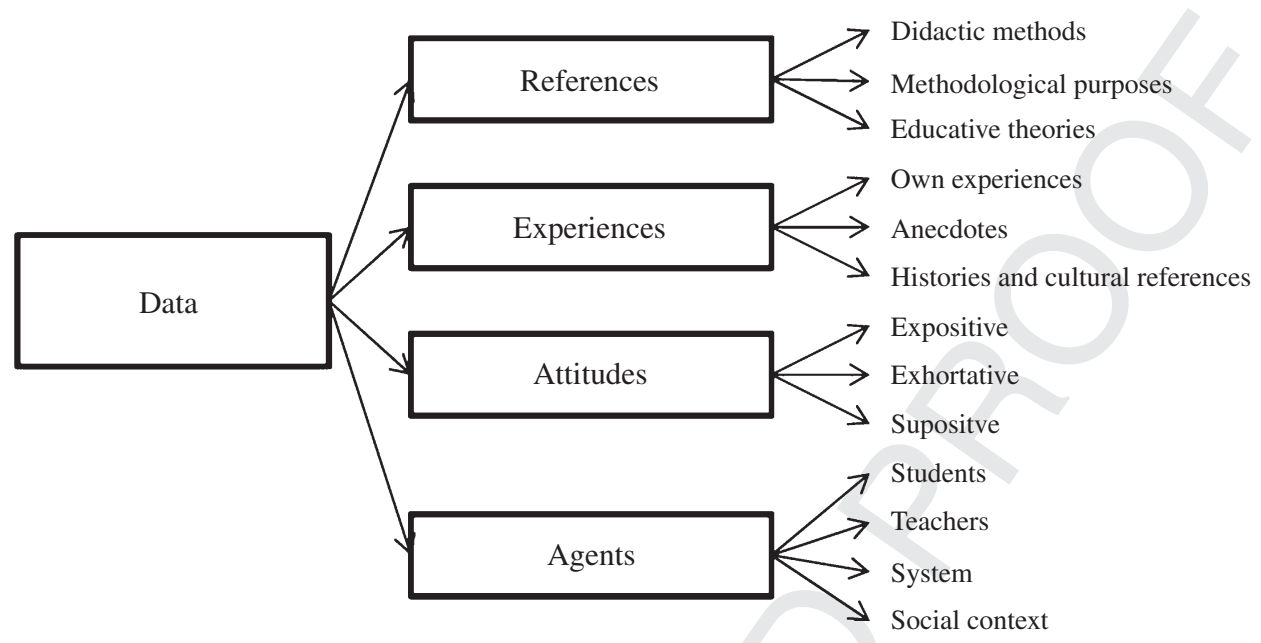

Figure 1. Graphical representation from data collection.

Our aim was, therefore, to articulate the information in such a way that it might help to extend knowledge on these matters (Bartel and Radocy 2002, 1111-3). Figure 1 presents the information that emerged from the responses and illustrates the way the data were systematically organised.

In order to clarify the discursive content analysis, we categorised responses according to their thematic content. Organised information on a series of different aspects allowed us to establish levels of selection and to group data. Each answer could provide useful information on some specific point that deserved highlighting.

\section{Findings}

The data were categorised into four main thematic clusters, thus facilitating its study and interpretation. In fact, this organisation was not predetermined but arose as a result of the analysis of the information obtained. The categories that emerged are indicated below.

\section{Category 1: Specific guidelines and recommendations}

This category includes the expository responses that offer specific recommendations which, according to the respondents, may promote or improve the pursuit of positive experiences in formal music classrooms settings.

It is assumed that no single proposal will apply to each and every educational reality. We understand, therefore, that there is no single universal answer and unconditional 'right way' that will guarantee success in music education in any context. Conversely, we believe that each educational activity should be adapted to the particular setting in which it is to be carried out. In this sense, the success or failure of the proposal will necessarily be subject to such adaptation.

Table 2 reports some of the answers from experts in this category. The analysis of these responses enabled us to establish thematic similarities that we considered to be of particular note. Some ideas emerged as a recurring leitmotif from the responses. 
Table 2. Responses to question referring to Category 1.

\begin{tabular}{lcl}
\hline $\begin{array}{l}\text { Response } \\
\text { sub-categories }\end{array}$ & $\begin{array}{c}\text { Number of } \\
\text { responses }\end{array}$ & \multicolumn{1}{c}{ Examples of excerpts } \\
\hline $\begin{array}{l}\text { Significant and } \\
\text { autonomous } \\
\text { learning }\end{array}$ & 7 & $\begin{array}{l}\text { Pep Alsina i Masmitjà (University of Barcelona, Spain): } \\
\text { From a constructivist approach, positive musical } \\
\text { practices are promoted from meaningful learning: } \\
\text { learning with meaning can only be achieved through the } \\
\text { involvement of the learner. } \\
\text { David Hargreaves (Roehampton University, London, } \\
\text { UK): One key aspect of a successful approach is that the } \\
\text { pupil is engaged and self-motivated rather than simply } \\
\text { following instructions from a teacher. } \\
\text { Wolfgang Dietrich (University of Innsbruck, Austria): Let } \\
\text { people express themselves. Do not regulate harmonies. } \\
\text { Celebrate the vernacular and expressive diversity. }\end{array}$ \\
& &
\end{tabular}

Care for students' social contexts
Keith Swanwick (Institute of Education, University of London, UK): (1) Concern for musical materials, expressive character and the linking of phrases into form. (2) Care for the music of students. (3) Care for musical fluency and easy aural exchange of musical ideas. David Hargreaves (Roehampton University, London, $U K)$ : It differs widely from country to country: in Eastern countries there is a strong emphasis on the spiritual and moral virtues that music can promote, whereas in the West we tend to stress individual creativity and expressiveness.

John O'Flynn (University of Limerick, Ireland): In my view, the key principles include [...] engagement with local, national and trans-national musical cultures. Federico Mayor Zaragoza (Former Director General of UNESCO, President of the Foundation for a Culture of Peace of Madrid): Each person is unique, culturally and biologically, in every moment of his or her existence. The limit of diversity, our greatest asset, is this uniqueness. [...] Coming closer to each person, discovering his or her characteristics and promoting the best traits of his or her identity is the great task of education. To be educated is to be yourself and act on your own decisions and to never take orders from anyone.

John O'Flynn (University of Limerick, Ireland): [ . . ] artistic and aesthetic engagement and development through music making and responding; [...] reflection on music per se, and reflection on music as a social agent. Wilfried Gruhn (University of Music, Freiburg, Germany): In my view, the core principle in music education is teaching and learning music musically, i.e. not learning facts about music, but getting enabled to merge into musical activities by implicitly knowing musical procedures. 
Table 2 (Continued)

\begin{tabular}{|c|c|c|}
\hline $\begin{array}{l}\text { Response } \\
\text { sub-categories }\end{array}$ & $\begin{array}{l}\text { Number of } \\
\text { responses }\end{array}$ & Examples of excerpts \\
\hline & & $\begin{array}{l}\text { Carmen Ramírez Hurtado (University of Granada, } \\
\text { Spain): It is important that any principle always connects } \\
\text { the intellectual with the experiential, and as the trend of } \\
\text { the last two decades has been to emphasize practice, I } \\
\text { also want support the connection with the theory: I } \\
\text { cannot have a positive experience from what I do not } \\
\text { understand. } \\
\text { Liora Bresler (College of Education, University of Illinois, } \\
\text { Urbana-Champaign, USA): I think that the effect of } \\
\text { music is kinesthetic, deeply experiential. And yes, there } \\
\text { are aspects that are considered 'cognitive', like good } \\
\text { form, or counter-point according to some traditions. But } \\
\text { ultimately we respond to that on that very fundamental } \\
\text { level. }\end{array}$ \\
\hline
\end{tabular}

Three main sub-categories were created to report these basic ideas, which reflect the aforementioned argumentational intersections.

\section{Category 2: Learning music making music}

Among all the responses to the research question, one idea emerged as highly significant. Perhaps the most strongly voiced recommendation to ensure that music education pursues positive experiences is that which rejects the focus on learning music theory. In this sense, without ignoring conceptualisations on the musical phenomenon, the experts highlighted the need to promote praxial approaches in music learning, so that music making can be the foundation on which music education is built.

\section{Extract from responses related to Category 2:}

Lucy Green (Institute of Education, University of London, UK): Well, I think a fundamental principle of music education is it must be about music; not about how to write music, how to analyse music, how to theorise about music or about understanding music history and musical facts and figures. They are important aspects of music in education but they're not fundamental and without the experience of music-making, none of those activities carries much value. So, putting music-making at the heart of music education is very important, to me.

Thomas Regelski (University SUNY, Fredonia, USA; Helsinki University, Finland): First, the need to regard music as social praxis rather than as a collection (canon) of aesthetic objects (or 'works'): more precisely, to regard the collective noun as a verbform, 'musicking' (following Christopher Smalls' book of that title, or 'musicking', following David Elliott in Music Matters, Oxford, 1995; the two concepts are not entirely the same however; Small's includes far more of the social, while Elliott's focuses on the making of or listening to the sounds). Thus, as mentioned above (and as championed long ago by Dewey), music education should be premised on 'learning by 
Table 3. Responses to question referring to Category 3.

\begin{tabular}{|c|c|c|}
\hline $\begin{array}{l}\text { Response sub- } \\
\text { categories }\end{array}$ & $\begin{array}{l}\text { Number of } \\
\text { responses }\end{array}$ & Examples of excerpts \\
\hline $\begin{array}{l}\text { The teacher as a } \\
\text { cultural and } \\
\text { learning } \\
\text { environment } \\
\text { manager. }\end{array}$ & 9 & $\begin{array}{l}\text { Steve Dillon (Queensland University of Technology, } \\
\text { Brisbane, Australia): If we do however decide to } \\
\text { initiate the student into a musical discourse, then } \\
\text { perhaps we can consider first the student as a maker. } \\
\text { We can then build an environment for them to be } \\
\text { playful in so that they can encounter musical } \\
\text { knowledge. } \\
\text { Alda Oliveira (University of Bahia, Brasil): I } \\
\text { recommend that the teachers or every person that } \\
\text { deals with music education practices consider, not } \\
\text { only the methods of teaching music, but also } \\
\text { specially the other variables that surround the } \\
\text { educative process, such as the sociocultural context, } \\
\text { the different characteristics of the individuals and the } \\
\text { groups, the repertoire and the contents to be taught. } \\
\text { Lucy Green (Institute of Education, University of } \\
\text { London, UK): Another important factor [...] is to } \\
\text { give students opportunities to bring their own music } \\
\text { into the classroom - they may not bring all the music } \\
\text { that they like into the classroom because they may be } \\
\text { embarrassed about some of the music that they like, } \\
\text { but at least, there will be some music that they do like } \\
\text { that they can bring to the classroom - and showing } \\
\text { respect for that music, and enabling students to find a } \\
\text { way to reproduce that music themselves. Not to sit in } \\
\text { the classroom and listen to it, but actually create and } \\
\text { recreate that music. }\end{array}$ \\
\hline
\end{tabular}

Considering learning 7

Nicolás Oriol de Alarcón (Complutense University of difficulties: plural and diversified educational activities. 
Table 3 (Continued)

\begin{tabular}{|c|c|c|}
\hline $\begin{array}{l}\text { Response sub- } \\
\text { categories }\end{array}$ & $\begin{array}{l}\text { Number of } \\
\text { responses }\end{array}$ & Examples of excerpts \\
\hline & & $\begin{array}{l}\text { Silvia Malbrán (University of Buenos Aires, } \\
\text { Argentina): To acknowledge diversity, the first } \\
\text { requirement for a teacher is to be an effective } \\
\text { observer of each student in his or her group; the } \\
\text { second is to note how many levels of difficulty a } \\
\text { certain task has, in order to accurately assign each } \\
\text { student to their optimum level; the third is to expect } \\
\text { from each student what he or she can actually do, } \\
\text { rather than imposing an achievement according to } \\
\text { standards related to age and maturity which are not } \\
\text { always reliable indicators. }\end{array}$ \\
\hline $\begin{array}{l}\text { Promoting collective } \\
\text { practices and } \\
\text { participatory } \\
\text { music. }\end{array}$ & 5 & $\begin{array}{l}\text { Nicolás Oriol de Alarcón (Complutense University of } \\
\text { Madrid, Spain): A breakthrough in the organization } \\
\text { of the current [Spanish] music curriculum, entails } \\
\text { that music is aimed at the transmission of culture and } \\
\text { values in today's society. At an interpersonal level, } \\
\text { most of the activities proposed in the musical praxis } \\
\text { are cooperatives. [. . .] Collective music activities and } \\
\text { different individual projects undertaken in the school } \\
\text { throughout the course can help integrate students. } \\
\text { Thomas Regelski ( University } S U N Y \text {, Fredonia, USA; } \\
\text { Helsinki University, Finland): Participatory musics, } \\
\text { in contrast, are by far the norm in the world and they } \\
\text { maximize sociality since there is no performer/ } \\
\text { audience distinction and musicking is entirely about } \\
\text { promoting sociality. The democracy of participatory } \\
\text { musicking is itself educative. }\end{array}$ \\
\hline
\end{tabular}

doing' this or that musical praxis (or multiple ones). One cannot study 'music' in general, or promote 'appreciation' by teaching concepts about music. Musical experience, per se, is already concepts in action: teaching concepts only puts verbal labels on what students already can perceive and experience as a result of their cultural situatedness (e.g., fast/slow music).

\section{Category 3: The role of the music teacher}

All such guidelines and recommendations can refer to many aspects of music education: the nature of contexts and educational environments and spaces, styles and genres in particular, educational curricula or different aspects of musical practices and music teaching. Among them, those which identify the music teacher as a key figure in the teaching-learning process are noteworthy. The respondents referred to this role of the educator, which emerged as the third of the categories noted in the research.

Depending on the nature of the responses, we created different sub-categories referring to diverse thematic focuses. Table 3 reflects the organisation established based on the data obtained. 


\section{Category 4: Recommendations for specific proposals and models}

Understanding the theoretical foundations of classical authors in music education, and discovering new proposals for teaching and learning music are necessary and, at the same time, fascinating tasks in music teaching. A good music teacher not only brings originality, participates in the creation of educational and musical proposals, but also knows and recognises the work which other educators, from their experience, share and contribute to the research landscape. For this reason, respondents suggested that the implementation of specific educational proposals can facilitate positive musical experiences in the music classroom.

\section{Extract from responses related to Category 4:}

Marcelo Giglio (Haute Ecole Pédagogique BEJUNE, Bienne, Switzerland): Elliott's praxial philosophy ... Engeström's activity theory may inspire us... The psychocultural approach from the education of J. Bruner opens up new spaces of meaning among students.

Andrea Giráldez Hayes (University of Valladolid, Spain): There are numerous theories that, taken together, provide support to meaningful music practices and experiences. Interesting contributions can be found from the proposals of the first pedagogicmusicians (especially Kodály, Willems or Orff), through the English 'teachers' who began their work in the 60s and left important contributions (Paynter, Self, Swanwick, etc...), to some of the current works, most notably those of Lucy Green for her exploration of musical practice in non-formal education contexts as a model for music education in schools.

Alda Oliveira (University of Bahia, Brazil): Recommendations to teachers according to the PONTES Approach (Oliveira 2005).

Steve Dillon (Queensland University of Technology, Brisbane, Australia): Perhaps the best philosophy comes from the pragmatist John Dewey's Art as Experience (2005) which simply recognizes the nature of the experience as phenomenological. Whilst the Western world seems to argue Reimer's aesthetic and Elliot's praxis approach both these philosophies are firmly placed within a US band and orchestral approach to music making and transfer of the philosophies requires significant cultural reframing. Methods such as Kodaly, Orff and Dalcroze also must be considered in their holistic context of being rooted in nationalism of the late 19th early 20th century. While they hold important traditional values and practices they too are limited in a 21 st century digital and multicultural classroom.

Wilfried Gruhn (University of Music, Freiburg, Germany): From my experience, the basic principles of Gordon's Music Learning Theory are very appropriate and applicable to students' music learning. However, it should not be seen as 'the' (only right) method or not as a 'method' at all, but as a basic general idea which has to be adapted to the particular demands of each social and cultural context.

\section{Discussion}

This study aims to reflect on the importance of acknowledging a practical, real approach to music education in schools. For this reason, the most significant criterion to emerge in music learning involves an educational perspective focused on the need for musicking. Music is, therefore, understood as a social praxis in which 
individual learning also depends, to some extent, on the practice and enjoyment of others. Encouraging creativity and personal expression is essential in bringing about meaningful musical learning. To this end, teachers should focus on developing people's musicality, by implementing a music education approach aimed at teaching music musically (Swanwick 1999).

The relationship between the praxis and the cognitive and conceptual aspect of musical experience is also explicitly referred to. The experimental experience of music should always be accompanied by a conceptual abstraction, which would support the significance of every educational activity. Intentionality is a key aspect of learning. In an educational process in which self-learning acquires value as an important exercise of autonomy, the music teacher may become a manager concerned to provide his or her students with an optimal educational environment.

The reference to the importance of the context surrounding educational processes is fundamental to the responses to the research question. This context is not only related to the geographical situation or to the dominant culture in which an educational musical practice takes place. Obviously, the dominant cultural reality will be determinant in organising a particular musical activity. However, the particular context also refers to personal and collective musical identities that could be recognised by participants who share a certain musical experience. In adapting their teaching work to every specific context, teachers should also take into account the progressive difficulties of the contents they address in their educational practice. Practices should be planned according to learning levels consistent with students' prior knowledge to ensure the success of educational activities. The choice of musical repertoire is also an important aspect to consider.

In this context, Spanish primary and secondary school music education should continue to make efforts to meet the challenges of today's social reality. The attempts made in the Spanish social contexts of previous decades to expand access to music education were unquestionably of great value. The incorporation of music education in general education led to an increase in the demand for more specific musical studies, in conservatories and music schools. Moreover, in agreement with Gordon (2007), the increased number of people directly engaged in music stimulated the growth of artistic life in our societies.

Efforts to broaden access to music education led to the need to integrate musical diversity in music teaching and learning. In Spain, in the 1990s and earlier, diversity was directly linked to students with specific educational needs. Demographic expansion as a result of migration processes, together with the educational law reform of the LOGSE, meant that in the closing years of the twentieth century and the beginnings of this century, diversity in classrooms was directly associated with cultural diversity. Numerous efforts and initiatives were set in motion to promote multicultural - and later on intercultural - music education in Spanish primary and secondary schools. Today, in a globalised context, musical diversity goes beyond cultural diversity, as musical identity, understood as an organic identity, is not necessarily shaped according to geographical and/or cultural boundaries. In classrooms, students from the same cultural context may have a huge musical diversity. In contrast, individuals from different cultural contexts can share great similarities in their musical identities or in their music learning processes. One of the biggest challenges facing Spanish primary and secondary schoolteachers is, indeed, acknowledging, discussing and integrating this diversity - becoming a musical 
manager (Dillon 2005) - even though they may often not be familiar with certain musical styles, and ensuring that participatory musical praxis entails the acquisition of meaningful and positive musical experiences.

In conclusion, this study finds that the concern to promote meaningful learning, involving students in musical practices, is a general guideline in current educational research. The current model in Spanish schools, which organises teaching guidelines based on learning through competences, is designed to improve meaningful education processes. It is through this kind of learning that it becomes possible to achieve musical practices involving positive experiences in the music classroom. But while music itself may foster complicity and synchronicities between people, it is the teacher's task to encourage this connection in his or her teaching activities. Numerous approaches have been developed to build the educational dynamics consistent with the pursuit of these experiences. However, none of these approaches is exclusive, but the proposals are complementary and can be put into practice in a particular educational setting.

Students' musical training is improved when participatory music approaches are successfully adapted to educational proposals that enable them to acquire positive musical experiences. Furthermore, these experiences will encourage students to extend their musical life in and beyond the music classroom, fostering the creation of intersubjective connections that lead to an improved interpersonal and social coexistence.

\section{Notes on contributors}

AQ2 Xxxxxx.

\section{References}

Bartel, L.R., and R.E. Radocy. 2002. Trends in data acquisition and knowledge development. In The new handbook of research on music teaching and learning, ed. R. Colwell and C. Richardson, 1108-27. New York: Oxford University Press.

Campbell, P.S. 1998. Songs in their heads: Music and its meaning in children's lives. New York and Oxford: Oxford University Press.

Campbell, P.S. 2004. Teaching music globally: Experiencing music, expressing culture. New York and Oxford: Oxford University Press.

Clarke, D. 2003. Musical autonomy revisited. In The cultural study of music, ed. M. Clayton, T. Herbert, and R. Middleton, 159-70. New York and London: Routledge.

Cohen, L., and L. Manion. 1990. Métodos de investigación educativa. Madrid: La Muralla.

Dewey, J. 2005. Art as experience. New York: Berkley.

Díaz Gómez, M., and G. Ibarretxe Txakategui. 2008. Aprendizaje musical en sistemas AQ3 educativos diversificados. Revista de Psicodidáctica 13, no. 1: 97-110.

AQ4 Dillon, S. 2005. El profesor de música como gestor cultural. Revista Electrónica Complutense de Investigación en Educación Musical 2, no. 3: 1-10.

Dillon, S. 2007. Music, meaning and transformation. Meaningful music making for life. Newcastle: Cambridge Scholars.

Elliott, D.J., ed., 1995. Praxial music education: Reflections and dialogues. New York: Oxford University Press.

Elliott, D.J. 2012. Personhood and music education. Paper presented at the 30th ISME World Conference on Music Education, July 15-20, in Thessaloniki, Greece, 451-9.

Feichas, H. 2010. Bridging the gap: Informal learning practices as a pedagogy of integration. British Journal of Music Education 27, no. 1: 47-58. 
Flinders, D.J., and C.P. Richardson. 2002. Contemporary issues in qualitative research and music education. In The new handbook of research on music teaching and learning, ed. R. Colwell and C. Richardson, 1159-75. New York: Oxford University Press.

Folkestad, G. 2005. Here, there and everywhere: Music education research in a globalised world. Music Education Research 7, no. 3: 279-87.

Folkestad, G. 2006. Formal and informal learning situations or practices vs formal and informal ways of learning. British Journal of Music Education 23, no. 2: 135-45.

Gordon, E.E. 2007. Sequences in music learning: A contemporary music learning theory. Chicago: GIA Publications.

Green, L. 1988. Music on deaf ears: Musical meaning, ideology and education Music and society. Manchester: Manchester University Press.

Green, L. 2002. How popular musicians learn: A way ahead for music education. Aldershot: Ashgate.

Green, L. 2003. Why 'ideology' is still relevant for critical thinking in music education. Action, Criticism, and Theory for Music Education 2, no. 2: 2-20.

Green, L. 2005. Musical meaning and social reproduction: A case for retrieving autonomy. Educational Philosophy and Theory 37, no. 1: 77-92.

Green, L. 2008. Music, informal learning and the school: A new classroom pedagogy. Aldershot: Ashgate.

Honneth, A. 1996. Reconocimiento y obligaciones morales. Revista Internacional de Filosofia

AQ5 Política 8: 5-17.

Honneth, A. 1997. La lucha por el reconocimiento: Por una gramática moral de los conflictos

AQ6 sociales. Barcelona: Crítica.

Ibarretxe Txakartegi, G. 2005. Cultural diversity and music education in navarre: Steps towards an intercultural perspective in primary school. In Music in schools for all children: From research to effective practice. Proceedings of the 14th international seminar of the music in school \& teacher education commission (granada, spain, 5-9 july, 2004), ed. M. Mans and B.w. Leung, 121-35. Granada: Editorial Universidad de Granada/ISME.

Ibarretxe Txakartegi, G. 2006. Imaginarios e identidad juvenil en contextos cotidianos de

AQZ educación musical. Eufonía. Didáctica de la música 38: 73-86.

Ibarretxe Txakartegi, G., and M. Díaz Gómez. 2008. Metaphors, intercultural perspective and music teacher training at the University of the Basque Country. International Journal of Music Education 26, no. 4: 339-51.

Joseph, D., and J.E. Southcott. 2009. Opening the doors to multiculturalism: Australian preservice music teacher education students' understandings of cultural diversity. Music Education Research 11, no. 4: 457-72.

Karlsen, S. 2010. Boomtown music education and the need for authenticity-informal learning put into practice in Swedish post-compulsory music education. British Journal of Music Education 27, no. 1: 35-46.

AQ8 Latorre, A. 2003. La investigación-acción: Conocer y cambiar la práctica educativa. Barcelona: Graó,

Leppert, R., and S. McClary, eds., 1987. Music and society: The politics of composition, performance and reception. Cambridge and New York: Cambridge University Press.

Martin, P.J. 1995. Sounds and society: Themes in the sociology of music. Manchester: Manchester University Press.

McCarthy, M. 2010. Researching children's musical culture: Historical and contemporary perspectives. Music Education Research 12, no. 1: 1-12.

McClary, S. 1987. The blasphemy of talking politics during Bach year. In Music and society. The politics of composition, performance, and reception, ed. R. Leppert and S. McClary, 1362. Cambridge and New York: Cambridge University Press.

O'Flynn, J. 2005. Re-appraising ideas of musicality in intercultural contexts of music education. International Journal of Music Education 23, no. 3: 191-203.

Oliveira, A. 2004. Contextos de formación musical: Educación musical entre lo formal y lo

AQ2 informal: Músicos consagrados de Bahia (Brazil). In Mundos sonoros por descubrir. Selección de comunicaciones ISME 2004, ed. A. Giráldez Hayes, 8-15. Tenerife: Sociedad para la Educación Musical del Estado Español (SEM-EE). 
Oliveira, A. 2005. Music teaching as culture: Introducing the pontes approach. International Journal of Music Education 23, no. 3: 205-16.

Regelski, T.A. 2004. Social theory, and music and music education as praxis. Action, Criticism, and Theory for Music Education 3, no. 3: 2-52.

Regelski, T.A. 2009. Curriculum reform: Reclaiming "music" as social praxis. Action, Criticism, and Theory for Music Education 8, no. 1: 66-84.

Reimer, B. 1993. Music education in our multimusical culture. Music Educators Journal 79, no. 7: 21-6.

Shepherd, J., P. Virden, G. Vulliamy, and T. Wishart, eds., 1977. Whose music? A sociology of musical languages. London: Latimer.

Small, C. 1977. Music, society, education: A radical examination of the prophetic function of music in western, eastern and African cultures with its impact on society and its use in education. London: John Calder.

Swanwick, K. 1968. Popular music and the teacher. Oxford: Pergamon.

Swanwick, K. 1984. Some observations on research and music education. British Journal of Music Education 1, no. 3: 195-204.

Swanwick, K. 1999. Teaching music musically. London: Routledge.

AQ10 Torrego Egido, L. 2005. La educación a través de la canción de autor. Revista de Educación 338: $229-44$.

Väkevä, L. 2010. Garage band or garageband ${ }^{\circledR}$ ? Remixing musical futures. British Journal of Music Education 27, no. 1: 59-70.

Volk, T.M. 1998. Music, education, and multiculturalism: Foundations and principles. New York and Oxford: Oxford University Press.

Vulliamy, G., and E. Lee. 1976. Pop music in school resources of music series, New ed. Cambridge and New York: Cambridge University Press.

AQ11 Vygotski, L.S. 1971. Psychology of art. Boston: Massachusetts Institute of Technology Press.

Wolff, J. 1987. The ideology of autonomous art. In Music and society. The politics of composition, performance and reception, ed. R. Leppert and S. McClary, 1-12. Cambridge and New York: Cambridge University Press.

Wright, R., and P. Kanellopoulos. 2010. Informal music learning, improvisation and teacher education. British Journal of Music Education 27, no. 1: 71-87. 